\title{
Comprehensive Analysis on the Performance and Material of Automobile Brake Discs
}

\author{
Wanyang Li, Xuefeng Yang *, Shouren Wang, Jupeng Xiao and Qimin Hou
}

School of Mechanical Engineering, University of Jinan, Jinan 250022, China; maidiyang123@163.com (W.L.); me_wangsr@ujn.edu.cn (S.W.); xiaojupeng1113@163.com (J.X.); houqimin0313@163.com (Q.H.)

* Correspondence: me_yangxf@ujn.edu.cn; Tel.: +86-130-7536-2913

Received: 20 February 2020; Accepted: 13 March 2020; Published: 15 March 2020

\begin{abstract}
This article reviews the current status of automotive brake disc research and the prospects for future research. At present, the research of brake disc performance mainly includes thermal conductivity, thermal fatigue resistance, wear resistance, and brake noise. It is found that a new alloy composite, heat treatment process, ceramic composite, new structure, and new materials are emerging. At the same time, it was found that ceramic and resin were used as the matrix, fiber materials were used as reinforcements to prepare brake discs, the addition of new fillers and the study of special reinforcement materials have become new hotspots in the study of brake discs. In the future development, carbon-fiber ceramic brake discs may become the main research focus of brake discs.
\end{abstract}

Keywords: alloy material; composite material; fiber materials; reinforcing material; brake disc

\section{Automotive Brake Analysis}

\subsection{Analysis of External Conditions of Automobile Braking}

Braking is quite a complicated process, and it is often affected and constrained by a variety of environmental conditions. By analyzing the braking process of the car, it can be found that the overall process can be divided into two major stages. The first phase is the reaction phase before the driver makes a braking decision. Additionally, the distance generated within the reaction time is the "reaction distance". The second stage is from the beginning of braking until the car completely stopped. Additionally, the distance generated within the braking time is the "braking distance". In general, people's braking response time is between 0.3 and $1.0 \mathrm{~s}$. The main factor affecting automobile braking is the road adhesion coefficient. The exact analysis is shown in Tables 1 and 2.

Table 1. Influence of different adhesion coefficients on brake distance.

\begin{tabular}{ccccc}
\hline & Speed $/\left(\mathbf{k m} \cdot \mathbf{h}^{\mathbf{- 1}}\right)$ & $\mathbf{1 5 0}$ & $\mathbf{1 2 0}$ & $\mathbf{9 0}$ \\
\cline { 1 - 4 } Adhesion Coefficient & & 151.08 & 106.69 & 69.39 \\
1.0 & 189.02 & 130.99 & 83.06 \\
0.7 & 25 & 23 & 20 \\
\hline
\end{tabular}

It can be seen that the smaller adhesion coefficient contributes to the longer braking distance, the longer corresponding braking time, and the higher probability of a brake safety accident. At the same time, the load of the car will affect braking. The car brake discs must have excellent braking performance to meet the car's braking needs under different road conditions.

Different friction conditions also have important effects on the friction and wear behavior of brake discs. Experimental studies have been performed on the slippage of three types of brakes on iron 
discs. They are named low-metal (LM) brake discs, semi-metal (SM) brake discs, and non-asbestos organic (NAO) brake discs. It studied the average friction coefficients of SM, LM, and NAO brake discs under friction steady state. The study found that as the contact pressure and sliding speed increase, the friction coefficient and specific wear rate would decrease [1].

At present, disc brakes are used in automobiles and drum brakes are used in heavy vehicles. With the requirements of new technical performance, the application of disc brakes in large cars will gradually be promoted.

Table 2. The relation between braking distance adhesion coefficient and driving speed.

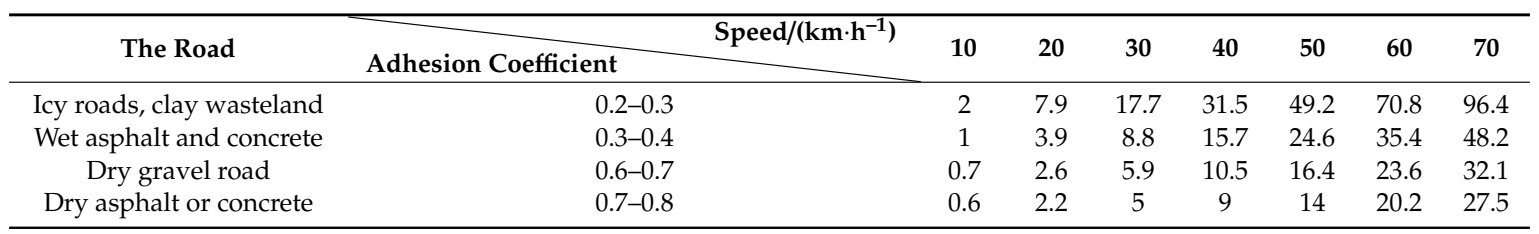

\subsection{Working Analysis of Brake Discs}

In the automobile transmission system, attached to the brake discs, the wheel hubs rotate with it. The automobile braking mainly relies on the friction between brake pads and brake discs. The kinetic energy of the high-speed rotating wheels is converted into a large amount of thermal energy through the braking system, which puts forward requirements on the heat dissipation and thermal conductivity of the brake discs. During the braking process, the heavy load on the brake discs and the severe friction between the brake discs and brake pads require the discs to resist fatigue cracks and deformation, improve the wear resistance of the material surface, and reduce brake noise.

In the process of friction braking, the friction system generates a boundary film on the friction interface, which is different from the two matrix materials. Additionally, its composition and structure are complex and diverse [2]. It will become an important influencing factor of automobile braking.

There is a reliability problem during the life cycle of the brake discs. The use of automobile brakes will inevitably lead to the reduction of their reliability. Studies have demonstrated that there are many optimization methods and analysis methods for brake disc reliability. An analytical model was established to describe the brake disc by using random parameters and random process analysis [3].

\section{Brake Disc Performance Analysis}

Cast iron is a common material for automobile brake discs. Many researchers have pointed out that vermicular graphite cast iron has relatively good friction and wear performances. Additionally, it is used as the base materials for brake discs in most automobiles.

Gray cast iron has vibration damping, abrasion resistance, thermal fatigue resistance, compactness, and other performance properties. The above features, a variety of superior properties, and cheap prices make gray cast iron the first choice of today's foundry industry.

The quantity, shape, length, and distribution of graphite in gray cast iron have a significant effect on the mechanical properties of cast iron. Graphite in gray cast iron has a variety of distribution shapes. According to the graphite distribution shape, there are six types, A, B, C, D, E, and F.

A-type (straight flake) graphite is a uniformly distributed graphite structure formed by hypoeutectic gray iron when the eutectic property is high and the degree of subcooling is small. It has less of an effect on the cleavage of metal. The pearlite content in cast iron with A-type graphite is high, so both strength and wear resistance are good. B-type (rose-like) graphite often appears in gray iron with high eutectic property and a high degree of subcooling. Due to the large degree of undercooling, the fine graphite eutectics that are initially formed grow faster and are distributed radially. The growth of graphite is slow and strip-shaped because of the release of the latent heat of crystallization, and finally, the three-dimensional shape of graphite is similar to a rose. The graphite in the core part is fine and dense. At the same time, ferrite is produced, which is detrimental to 
the properties of cast iron. Small amounts of B-type graphite are usually allowed. C-type (coarse slab or block) graphite is typical graphite of hypereutectic gray iron. Since the graphite is produced in the liquid state and has a considerable thickness, they are often connected or are very close to each other, and the surrounding is often ferrite, so the performance of cast iron is greatly reduced. Consider that gray cast iron is mostly hypoeutectic, C-type graphite is not allowed in any grade of gray iron (except for piston rings and some brake drum discs). D-type (dendritic point) graphite mostly appears in cast iron structures with low eutectic property or high undercooling. The reason is that the supercooling degree of molten iron is large, thus it is also called supercooled graphite. Undercooled graphite is often accompanied by undercooled ferrite, which is unevenly distributed in the form of dendritic points. Thus, it is not good for cast iron performance. E-type (dendritic) graphite is also an undercooled graphite. It is formed when the degree of subcooling is greater than that of D-type graphite. Therefore, its distribution is more uneven. The directionality is more obvious and the performance of cast iron is also more disadvantageous. F-type (star) graphite is the product of hypereutectic cast iron under extreme subcooling. Its abrasion resistance is good and it is also accompanied by a high-diffusion full pearlite matrix. Among them, primary graphite is C-type and F-type graphite, which is precipitated under the hypereutectic composition. Hypoeutectic cast iron has A, B, D, and E type graphite. Among them, A-type is evenly distributed and nondirectional. It improves the uniformity, stability, and strength utilization of cast iron.

Research on the wear of cast iron, under different temperatures and different load pressures, it was found that as the wear load increases, the change in the wear rate increases slowly, then rapidly, and finally flattens. The average friction coefficient decreases rapidly and then flattens out. Sugishita et al. [4] believed that the formation condition of the surface graphite film affected the friction and wear behavior of cast iron. Additionally, they studied the formation of graphite film during the wear process of gray cast iron by pin-disk friction and wear tester. Eyre et al. [5] found that $90 \%$ of the wear scar area was covered by a red or black film even under slight wear in the wear of flaky gray cast iron and ductile iron. The black film has good adhesion. The red film is not only easy to be powdered but also easy to peel off. Montgomery et al. [6] thought that these surface coatings were mainly derived from graphite in the cast-iron structure. However, some were also derived from iron oxides $\left(\mathrm{Fe}_{3} \mathrm{O}_{4}\right)$. Terheci [7] conducted a more in-depth study on the wear mechanism of cast iron materials and proposed a physical model of cast iron wear. Based on the noise characteristics of friction-wear performance and friction process. The friction and wear of cast iron are proposed to be controlled by the formation of abrasive particles, detached from the friction replica and captured by the friction surface again by using a pin-disk experiment device. The model is shown in Figure 1. Referring to the peeling mechanism shown in Figure 1a. Due to fatigue, the shearing effects of friction between friction pairs, etc. will appear on the friction surface. During the friction process, the abrasive particles may be recaptured by the friction surface by the two mechanisms shown in Figure 1b. Abrasive particles can cause a significant increase in friction, either during spalling or during recapture. 


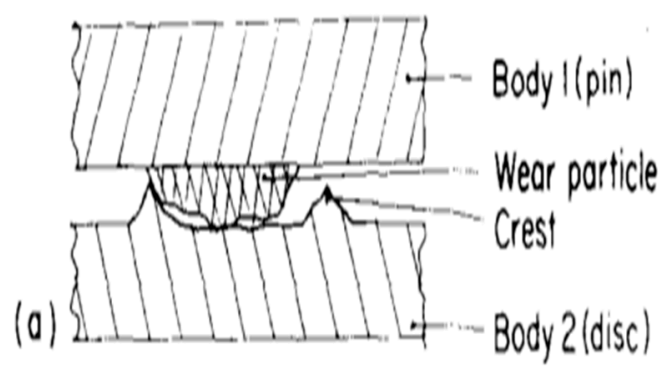

(b)
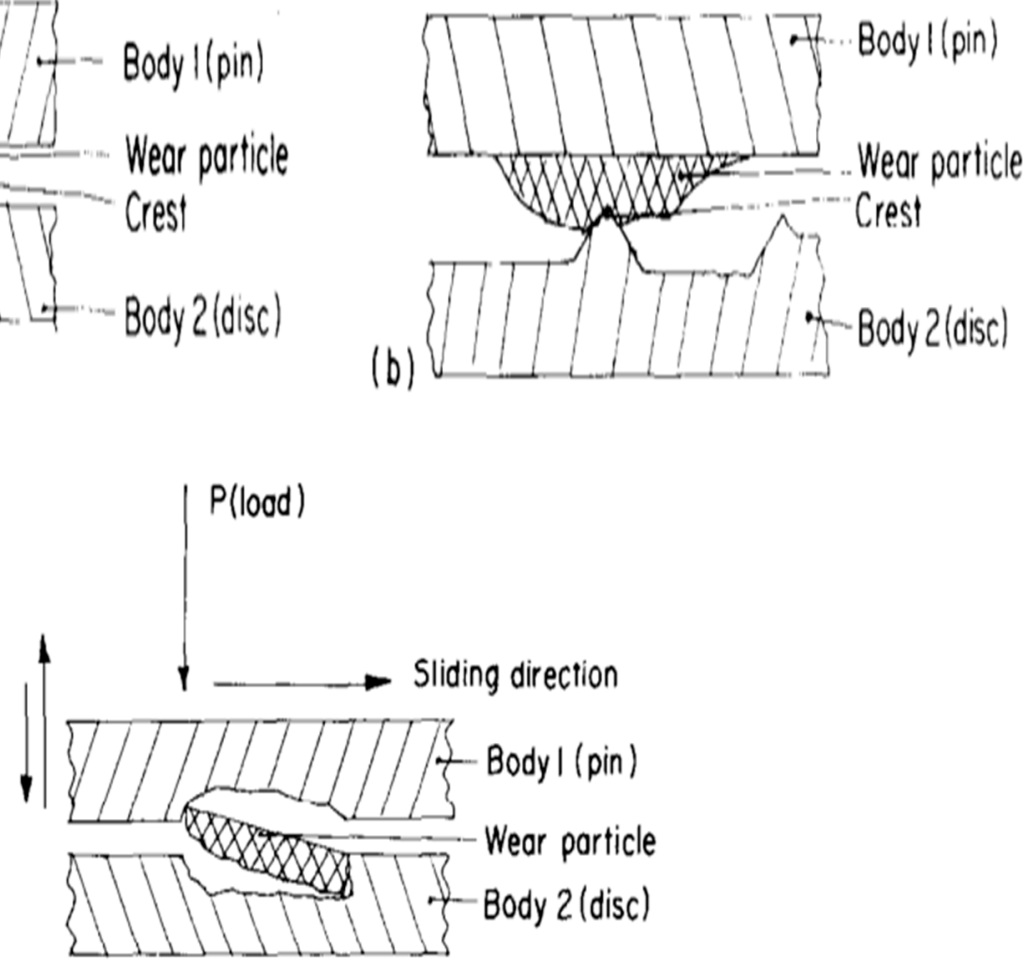

Figure 1. Schematic diagram of particle removal and entrapment. (a) Particle removal. (b) Two ways of particle entrapment.

\subsection{Thermal and Thermal Analysis}

In the process of friction between brake discs and brake pads, for the thermal conductivity of the brake discs is higher than that of the brake pads, most of the heat is transferred to the brake discs during the friction process. It accounts for approximately $60-70 \%$ of the total heat. The heat accumulated on the brake discs must be transferred and dissipated. Otherwise, overheating will lead to thermal fatigue failure to the brake discs.

There are many thermodynamic problems between the friction pairs of the braking system. Majcherczak [8] measured the heat generation and distribution process under transient conditions by using micro and macro methods. It is different from the case where the contact surface temperature is assumed to be equal in the classical models. They introduced a third body layer with a constant heat generation rate between the friction pairs. In addition, they used this model to study the heat distribution between the friction pairs. Then they compared the results with the results of the classic model. Aleksandrov and Nosko [9] described the relationship about the brake discs thermal resistance, different parameters of friction materials, and temperature distribution. In the study, they found that the average temperature of the brake disc and the brake pad is different. Additionally, they used a finite element model to simulate the influence of the thermal resistance of the friction material of the brake disc and the pad on the heat distribution. Benseddiq et al. [10] used a two-dimensional finite element thermodynamic model to predict the wear and temperature distribution of the brake disc and pad surfaces. Based on this, they discussed the different performances of friction and wear performance of brake discs with different structural designs.

There are three ways of heat loss: heat conduction, heat radiation, and heat convection. Among them, heat conduction and heat convection became typical analysis directions for heat loss. Heat conduction is the main form of heat transfer in brake discs. The main aspect of the effect of heat conduction on the mechanical properties in brake discs is the superposition of thermal and mechanical stress. It has requirements on the thickness of the brake discs, the thermal conductivity of the materials, the connection results, and the air duct structures between the brake discs braking 
surface and the disc caps. For thermal convection, if the convective motion of the fluid is caused by an external force. It is called forced thermal convection. If the convective motion of the fluid is caused by the uneven density for temperature difference. It is called natural thermal convection. Each plane of the brake discs' surfaces have a thermal convection effect with the outside. For the interior of the air duct, changing the internal structure of the air duct can achieve the purpose of increasing turbulence, increasing the flow velocity and flow, and expanding the area of thermal convection. Thus, it can increase the heat transferred by thermal convection. For friction surfaces, if you want to increase the surface area of thermal convection, you can make grooves and holes. Additionally, if you want to increase the thermal convection coefficient, you can increase the brake discs' rotation speed, increase the turbulence intensity by scribing.

Based on the excellent thermal conductivity and heat dispersion of cast iron materials [11], it is widely used as the base material of automobile brake discs. Graphite plays an important role in improving the thermal conductivity of brake discs and the thermal diffusion coefficient of materials in cast iron. Differences in the constituent phases of graphite also lead to differences in thermal conductivity, as shown in Table 3. The content of graphite in cast iron is proportional to the thermal conductivity of materials.

Table 3. Thermal conductivity of constituent phases of cast iron.

\begin{tabular}{|c|c|c|c|c|}
\hline $\begin{array}{c}\text { Phase } \\
\text { Composition }\end{array}$ & Morphology & $\begin{array}{c}\text { 0-100 }{ }^{\circ} \mathrm{C} \text { Thermal } \\
\text { Conductivity/ } \\
\left(\mathrm{W} \cdot(\mathrm{m} \cdot \mathrm{K})^{-1}\right)\end{array}$ & $\begin{array}{c}\text { Phase } \\
\text { Composition }\end{array}$ & $\begin{array}{c}\text { 0-100 }{ }^{\circ} \mathrm{C} \text { Thermal } \\
\text { Conductivity/ } \\
\left(\mathrm{W} \cdot(\mathrm{m} \cdot \mathrm{K})^{-1}\right)\end{array}$ \\
\hline \multirow[t]{2}{*}{ Graphite } & Spheroidal graphite & 83.7 & $\begin{array}{l}\text { Ferrite } \\
\text { Pearlite }\end{array}$ & $\begin{array}{c}71.2-79.6 \\
50.2\end{array}$ \\
\hline & Flake graphite & $433.1-418.7$ & Cementite & 7.1 \\
\hline
\end{tabular}

\subsection{Thermal Fatigue Analysis}

Many wide and deep cracks are distributed on the surface of brake discs. It causes the brake disc performance to decline or even fail. The occurrence of cracks is closely related to thermal fatigue characteristics. When braking, the internal and external surfaces of brake discs will generate a huge temperature gradient. Additionally, at the same time, tensile stress is generated at the surface of materials [2].

Thermal decay is a phenomenon that the friction of the braking system causes the friction pairs' temperature to rise and the friction coefficient to decrease. Its essence is the dynamic lubrication of the lubricating film or air-cushion film generated between the brake friction pairs. For powder metallurgy materials, its resistance to heat decay is strong. For resin matrix friction materials, its resistance to heat decay is weak [12].

Hecht et al. [12] found that there is an approximately linear relationship between the thermal conductivity and carbon equivalent of gray cast iron. At the same carbon equivalent, the longer the graphite sheet, the better the thermal conductivity of gray cast iron.

Crack initiation, crack propagation, and crack instability propagation are the three stages of fatigue failure. Different types of cast iron have different thermal fatigue resistance. Figure 2 is the crack length analysis of different cast iron under the same conditions. Among them, the properties of three gray cast iron about A, B, and C respectively correspond to HT200, HT250, and HT300. It can be seen from the figure that the crack length of sample $C$ is the longest, the crack length of sample A and sample $B$ are similar. At the same time, the variation range of the crack of sample $C$ is the largest within a certain range. The HT300, corresponding to the sample C, has a relatively low graphite content, large strength, and large notch sensitivity. Sample $C$ has a small graphite content and weak thermal conductivity, so when braking, the sample's temperature difference between the inside and the outside will be large. It can result in large thermal stress. Therefore, the crack propagation speed of sample $C$ is faster than that of sample A and sample B. The graphite of the B sample is an A-type, and the A sample 
contains A-type graphite and a small amount of D type supercooled graphite. Although the thermal conductivity of type A graphite cast iron is greater than that of D type graphite [13]. The relatively coarse A-type graphite is conducive to crack propagation. This resulted in the crack propagation speed of specimen B being faster than that of specimen A after 180 cycles.

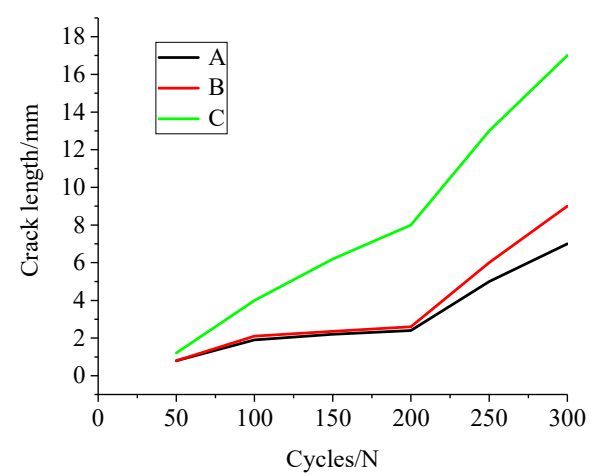

Figure 2. Thermal cycle times-average crack length curve.

It can be found that the fundamental structure of the cast iron is still pearlite and many small black spots are distributed around the graphite by observing the typical metallographic structure of the sample after the thermal fatigue test in Figure 3. The reason for this phenomenon may be that the cast iron sample was oxidized when it was exposed to air at the experimental high temperature.

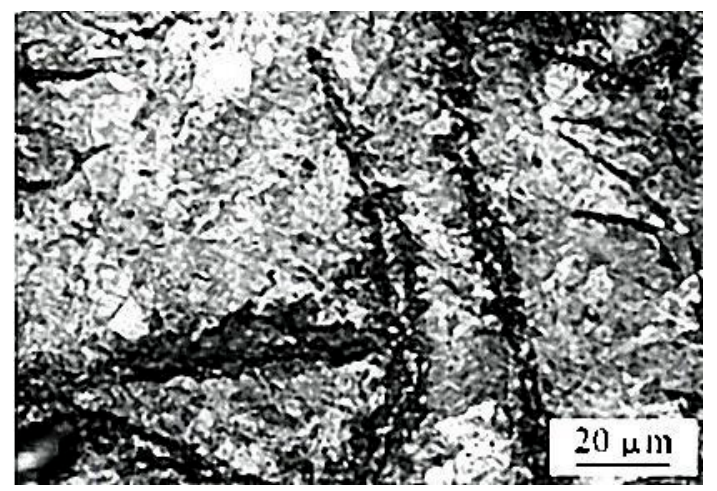

Figure 3. Metallographic structure after the thermal fatigue test.

\subsection{Wear Resistance Analysis}

The wear resistance is a key factor in the service life of brake discs. In the friction and wear process of brake discs and brake pads, abrasive wear and adhesive wear are the two main ways of friction loss. Under the pressure and friction of the pairing materials, when the hardness of the hard phase of the cast iron is greater than the hardness of the matrix, the abrasive wear gradually appears on the surface of the matrix. Therefore, the hard phase contacts the friction of the pairing materials to form the first friction surface. The matrix and graphite constitute the second friction surface.

According to the wear of brake discs and brake pads, the wear can be divided into three categories: mild wear, moderate wear, and heavy wear. The study found that different wear mechanisms of different microstructures have different wear mechanisms [3]. Mild wear, the friction surface is nearly intact and essentially free of deformation. The oxidized powder tightly covers the friction surface. Moderate wear, the friction surface is covered with discontinuous oxidation. There are microdeformation and large particles of abrasive debris. Heavy wear, the friction surface is severely deformed, the roughness is increased. Additionally, it produces band-like loose wear debris. 


\subsection{Noise Analysis}

Currently, the braking noise has become an increasingly important impact in automobile manufacturing. When braking, the brake discs and the pairs were changed from an elastic contact to plastic contact. From kinetic energy to thermal energy, organic materials began to transform. As a result, the friction coefficient dropped sharply, the braking torque decreased. The braking are slipping and sticking. Additionally, it produced different levels of noise. Some experiments [14] compared the laser speed test under room temperature and $100^{\circ} \mathrm{C}$. Figure 4 shows the results of the experiment. Experiments have found that for different friction materials, as the speed and temperature increased, the movement of friction noise to high frequencies would decrease. At low frequencies, it would cause the reduction of the friction noise [14].

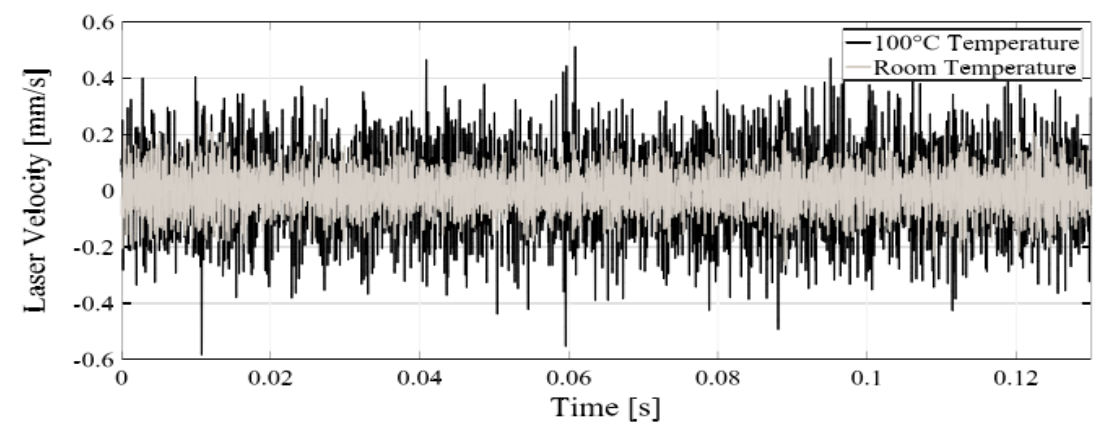

Figure 4. Comparison of the laser velocity test at room temperature and laser velocity test at $100{ }^{\circ} \mathrm{C}$.

Blaschke et al. [15] defined the contact properties of the brake friction interface, and they analyzed the brake screaming tendency using the complex eigenvalue method. Liu et al. [16] considered the effects of parameters such as brake pressure, brake disc speed, friction factor on system characteristic values and achieved the goal of eliminating brake screams by optimizing the characteristic values. Guillaume et al. [13] used the finite element model of the brake for modal analysis, and used the complex eigenvalue method to analyze the stability of the brake. Additionally, they studied the influence of the change of damping coefficient on the stability of the brake discs. Francesco [17] used a simplified finite element model of the brake to consider the friction changes in the frictional contact surface, and performed complex eigenvalue analysis and transient nonlinear analysis.

For different structures, the brake discs have different specific pressure distribution rules. With a wide initial braking speed and a small braking specific pressure, sufficient braking torque is obtained to maintain sufficient braking stability. Therefore, it is an effective method to choose the right material and ratio to reduce the brake noise.

Some scholars [18] studied different frictional contact methods and came to a relationship between the frictional sound pressure level $L p$ and the surface roughness $R a$. Swedish scholar Hammerstrom et al. [19] applied patterned sandblasting to the surface of the brake discs by sampling. On the one hand, the roughness of the local surface is increased, and on the other hand, the noise of the automobile brake system is reduced. The characteristics of the friction interface are critical for friction noise. There is a variety of researches and attempts on friction noise. At present, most researches focus on the influence of surface roughness on friction noise. It is an in-depth and unique research idea to build a groove-shaped texture on the friction surface. Additionally, its research direction is profoundly innovative.

The Taguchi method was founded by Dr. Taguchi of Japan. The core purpose of the Taguchi method is to make the designed products stable in quality and low in volatility. It makes the production process insensitive to various noises. The Taguchi is adopted for the robustness design of the brake noise. Its interference factor is the fluctuation of the friction factor. The study found that the key factors affecting brake screaming are the material, structure, operating conditions and environmental conditions of the braking [20]. Under the random normal distribution, the statistical characteristics of 
system eigenvalues and the sensitivity of parameters are analyzed by the Monte Carlo method [21]. It was found that modifying the backplate thickness of the brake, which increases the support stiffness, could improve the stability of the braking system and reduce braking noise. Using active and passive methods of piezoelectric materials to suppress brake noise is a relatively new method and idea on research.

\section{Brake Disc Manufacturing Analysis}

Graphite is the most basic component of frictional couples. The adjustment of the graphite content in the material can change the density, friction coefficient, and wear rate in brake disc materials. The material of the brake disc should not only have a good abrasion resistance but also a high and stable friction coefficient [22].

\subsection{Alloy Process}

There are two ways to improve the strength and hardness of nodular cast iron. One is using heat treatment and the other is using alloying [23,24]. The alloy element can improve and inhibit the properties of brake disc materials. We can choose the appropriate $\mathrm{Al}$ and element ratios to achieve the purpose of improving brake disc performance, increasing strength, and improving wear resistance. At the same time, the service life of the brake disc can be extended.

The laser cladding technology is an important method to improve the surface properties of materials. The tissue area of laser cladding is divided into three parts: the melting zone, hardened zone, and matrix zone. In the process of laser rapid solidification, the grains are refined, and the hard phase and new structure appear. It improves the wear resistance of the surface and the microstructure $[25,26]$. Additionally, by spraying an alloy coating on the surface of the cast iron materials, using a supersonic flame spraying method, the wear resistance of the materials will be improved.

The alloy elements $\mathrm{P}$ and $\mathrm{B}$ are added to the common parts of cast iron materials and form a hard phase, which increased the friction coefficient, reduced the wear rate and improved the friction and wear performance of frictional couples. The low melting point hard phase formed by $\mathrm{P}$ and $\mathrm{B}$ in cast iron illustrates its effect on the friction and wear properties of cast iron [7]. Since boron is a strong carbide-forming element, a low content of boron can play a role equivalent to the high content of phosphorus.

The research found that the appropriate ratio of ingredients and the reasonable selection of alloy elements such as manganese, chromium, molybdenum, antimony, copper, and trace elements stannum can improve brake disc performance. At the same time, they have a positive effect on the gray cast iron matrix and graphite of brake discs. However, not all metal elements have a positive effect on the performance of brake discs. Additionally, it is not that the more alloying elements added, the mechanical properties are better. Figure 5 of the experimental study [27] shows the relationship between the copper content and the average coefficient of friction. At $100{ }^{\circ} \mathrm{C}$, the increase of copper content from $0 \%(\mathrm{~V} 0)$ to $10 \%(\mathrm{~V} 10)$ did not lead to an obvious change of the friction coefficient. However, when the copper content increased to $30 \%$ (V30), the value of the coefficient of friction was significantly reduced. At 200 and $300{ }^{\circ} \mathrm{C}$, copper plays an important negative role. The friction coefficient decreases significantly with the increase of copper content. In other words, the presence of copper leads to a reduction in the coefficient of friction [27]. Therefore, the combination of alloying elements and the proper ratio of the alloying elements are extremely important.

Manganese dissolved in ferrite can increase its strength and hardness. The content of manganese affects the mechanical properties of materials. The low content of manganese dissolved in the ferrite plays a role of solid solution strengthening. The high content of manganese plays a substitution role to form alloy cementite. Alloy cementite is beneficial to the formation and refinement of pearlite, and it can improve strength and hardness, and reduce plasticity [28]. By optimizing the ratio of ingredients and adjusting the chemical composition, the performance of brake disc can be improved. 
Microalloying is an effective method to improve the mechanical properties of materials [29]. Small addition of the microalloying element niobium can refine the flake graphite in gray cast iron materials and improve material hardness, wedge pressure strength, and thermal cracking resistance.

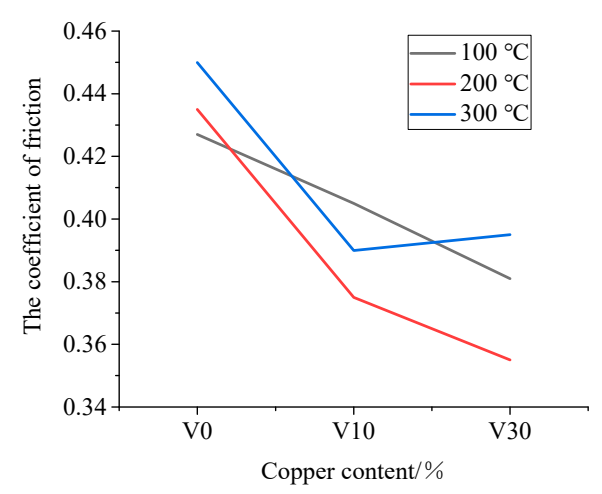

Figure 5. Average friction coefficient measured in the experiment.

\subsection{Heat Treatment Process}

The heat-treat has a very important role in improving the hardness, strength and wear resistance of brake disc materials. The heat-treat is commonly used in machining includes annealing, normalizing, quenching, tempering, carburizing, nitriding, carbonitriding, laser heat-treat, electron beam heat-treat, etc. The experimental research on the heat-treat of nodular cast iron found that its mechanical properties have produced significant changes. From the comparison of Figures 6-8 about the metallurgical structure, it can be found that its structure has changed significantly. The decarburization layer in the metallographic structure, as shown in Figure 9, is a disadvantageous factor that needs to be avoided as much as possible.

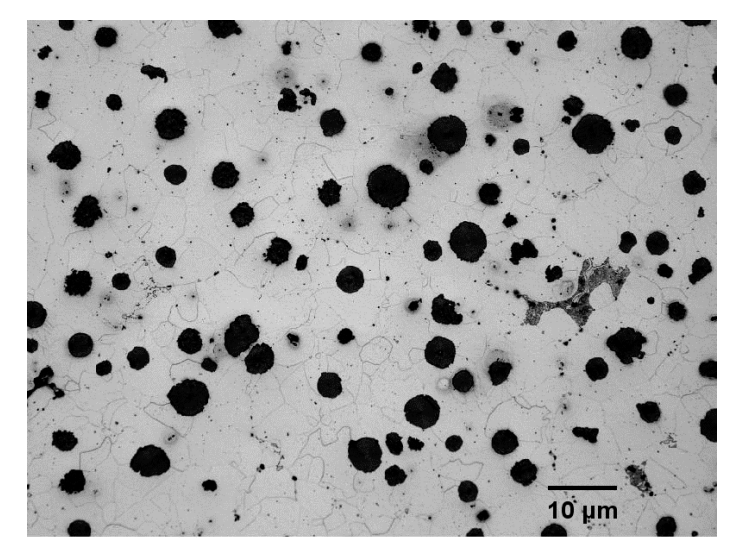

Figure 6. Microstructure of nodular cast iron without heat treatment.

In the normalization, a large amount of ferrite is converted to pearlite. The content of pearlite increases in the matrix. Additionally, the content of carbon increases. Thus, the process improves the strength, hardness, and wear resistance of nodular cast iron. In addition, it maintains a good performance of plasticity. However, a decarburized layer was generated on the surface of materials after normalizing treatment. It reduced the carbon content of the surface layer and decreased the strength and hardness of material surface. A large amount of ferrite is transformed into bainite after isothermal quenching. Lower bainite is a mechanical mixture that concluding carbon supersaturated flake ferrite and internally precipitated carbides. It has excellent strength, wear resistance, and toughness. However, its plasticity has been decreased.

The nitriding temperature required for ordinary gas is high and the holding time is long. This process has resulted in low production efficiency and serious energy waste [30]. The research 
on nitriding treatment of cast iron found that the wear of the matrix was mainly fatigue peeling. Additionally, it was accompanied by abrasive wear. The wear of the nitriding samples was peeling wear. Lattice distortion caused by nitriding treatment and residual compressive stress on the surface after nitriding inhibit crack growth. In addition, it increased abrasion resistance [31,32]. After nitriding treatment of HT250, a nitriding layer is formed on the surface. It not only improved the strength of the surface but also improved surface ability to resist plastic deformation [22,33]. It can be seen that the compound layer is uniformed and the tissue is dense by the cross-sectional view of the nitriding HT250 sample in Figure 10.

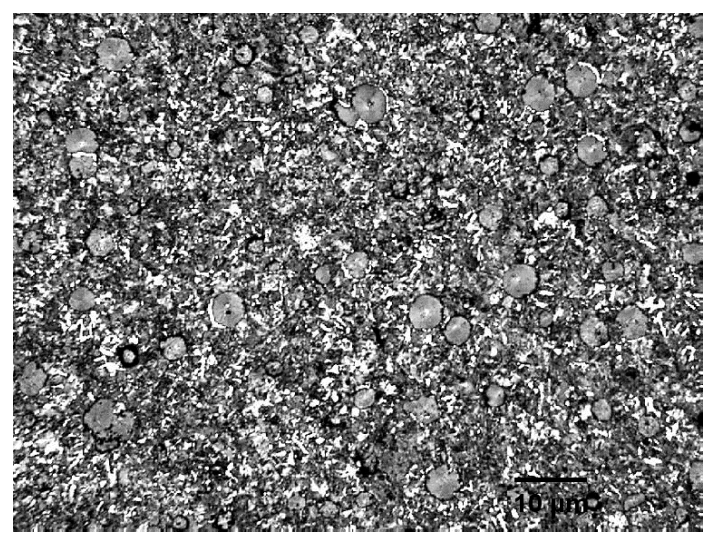

Figure 7. Microstructure of nodular cast iron normalized at $900{ }^{\circ} \mathrm{C}$.

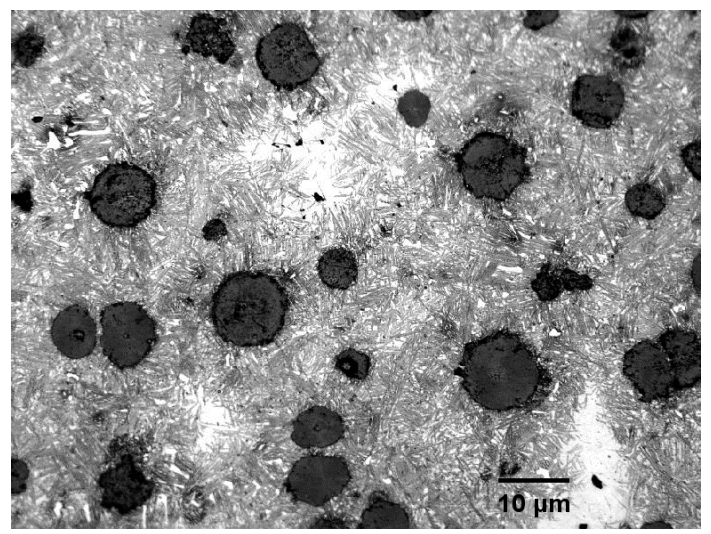

Figure 8. Microstructure of ductile cast iron isothermal quenched at $900+250{ }^{\circ} \mathrm{C}$.

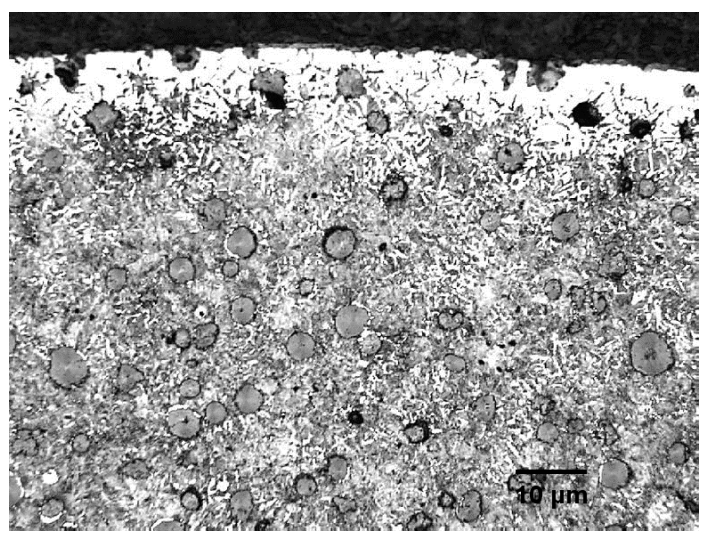

Figure 9. Microstructure of surface decarburization of ductile iron treated at $900{ }^{\circ} \mathrm{C}$. 


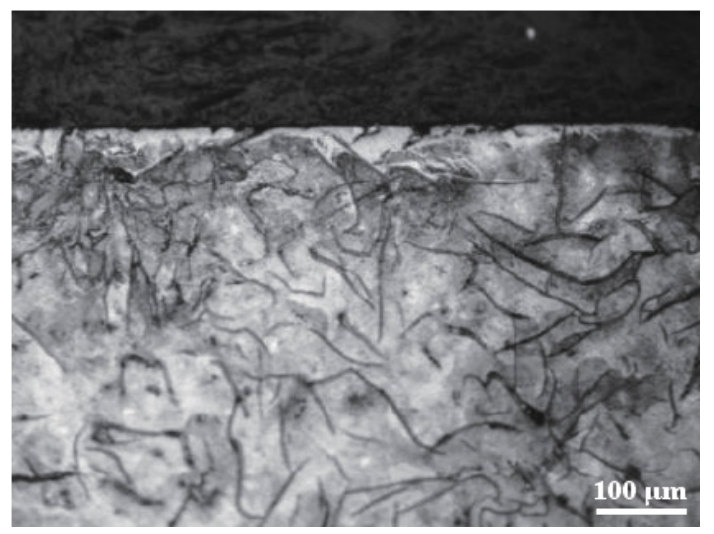

Figure 10. Optical micrograph.

When using different heat-treat temperatures to study carbon-carbon composites, it can be found that as the heat-treat temperature increases, the degree of graphitization of the composites increases. The friction factor increases with the increase of heat-treat temperature. Additionally the friction factor, linear wear, and mass wear all have peaked. The oxidation wear decreases with the increase of the heat-treat temperature. The degree of graphitization has a certain effect on the friction and wear properties of materials. Thus we can get the materials we need by properly controlling the degree of graphitization.

Therefore, to improve the performance of brake discs, we need to take appropriate inoculation ways to treat the material surface.

\subsection{Composite Material Technology}

At present, the application of composites to brake discs has become the mainstream direction about the contemporary automobile. The application and development of carbon-carbon composites, carbon fiber ceramic composites, and coating composite oxide film materials has made great contributions to the modification of brake discs.

Carbon-carbon composites have low density, high specific strength, high specific modulus, stable friction factor, low linear expansion coefficient, high thermal conductivity, good ablation resistance, good friction performance, and good thermal shock resistance. In particular, it can still maintain high strength performance at ultra-high temperatures. Additionally it can resist the adverse factors caused by the friction of brake discs. At the same time, the manufacture of antioxidation coatings with good oxidation resistance, low price, simple process, moisture resistance, and environmental protection has become the focus of competition among enterprises today. Figure 11 shows the morphological characteristics of carbon-carbon materials under the optical microscope. The (a)-(d) are test samples of hardness HS40, HS50, HS60, and HS70 respectively. The 1 represents the morphology characteristics of the surface close to the non-friction surface. The 2 is the morphological characteristics of $2 \sim 10 \mathrm{~mm}$ under the friction surface. It can be found that the base damage of the carbon-carbon materials brake disc is not more than $60 \mu \mathrm{m}$, which does not affect its structure.

In addition to the influence of the environment on the friction and wear behavior of $\mathrm{C} / \mathrm{C}$ composites, different braking torques, loads, braking speeds, and temperatures will affect the friction and wear behavior of C/C composites [34-36]. Under low energy conditions, granular abrasive debris is mainly formed on the surface of the composites. It increased the friction coefficient and wear rate. Under high-energy conditions, film-like wear debris is mainly formed on the surface of the composites, and its function is similar to solid lubricants. It reduced the friction coefficient and wear rate of the composites [37]. Awasthi [38] et al. considered that the wear mechanism of C/C composites includes the formation and transfer of the abrasive film. Friction debris is constantly generated on the brake disc surface by the pressure and the relative sliding of the friction surface. Additionally an abrasive film will be formed. Repeated sliding causes part of the wear debris to fall off. As the substrate wears, 
new abrasive debris forms a new abrasive debris film. In recent years, the comparatively excellent preparation method, the Chemical Liquid-Vapor Deposition (CLVD), was adopted by the United States and France, and has been made great achievements $[39,40]$. Through the study on the friction and wear properties of $\mathrm{C} / \mathrm{C}$ composites, composites with better friction and wear properties can be prepared. However, there are still various problems on the study of their friction and wear properties, which need to be solved.

High friction composites have the advantages of controllable friction coefficient, good friction resistance, high wear resistance, low noise, and stable performance in different working environments. Its development has gradually replaced other products in the rail transportation industry [41,42]. The raw materials of high friction composites are complex and diverse. They can be roughly divided into three categories: binders, reinforcing fibers, and fillers. Among them, fillers have the most significant effect on the friction and wear properties of high friction composites. The effect on the friction and wear performance to high friction composites mainly depends on the hardness, particle size, morphology, and distribution of the filler. The filler with good performance can increase the friction coefficient, reduce the wear performance, increase the high-temperature stability of the composite, and adjust product comprehensive mechanical properties. The filler with poor performance leads to increased wear of composites, reduced stability of friction coefficient, and accelerated damage of dual materials [43-46].

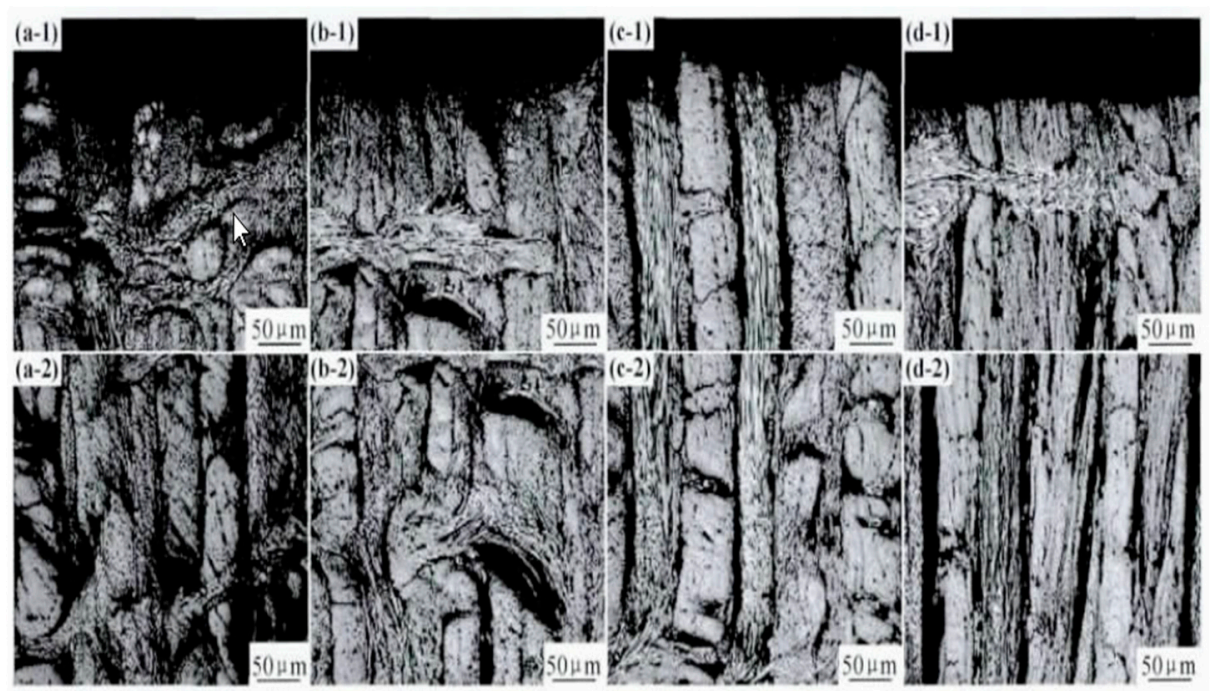

Figure 11. Surface morphology of the non-friction side and substrate of carbon-carbon materials with different surface hardness. (a-1,a-2) HS40; (b-1,b-2) HS50; (c-1,c-2) HS60; (d-1,d-2) HS70.

The new type of filler has a certain effect on the friction and wear properties of high friction composites. When the content of high-performance fillers is low, the wear mechanism is abrasive wear and adhesive wear, and the real contact surface is largely continuous in wear. When the content of high-performance fillers is high, the wear mechanism is abrasive wear and fatigue wear, the real contact area is reduced, and the crack appears. Cho et al. [47] found that small size zircon fillers will reduce the frictional stability of composites and increase the wear of composites. Bijwe et al. [48] compared the effects of nanofillers and microfillers on the friction properties of composites. The study has shown that nanofillers are more likely to form stable friction films and transfer films upon the surface of materials and dual materials. It increased friction stability and reduced material wear. As shown in Figure 12, the high-performance filler, a mixed filler, was prepared by a special process and a certain proportion. Additionally, its main components are graphite powder, $\mathrm{Al}_{2} \mathrm{O}_{3}, \mathrm{MoS}_{2}$, ferrous powder, etc. 


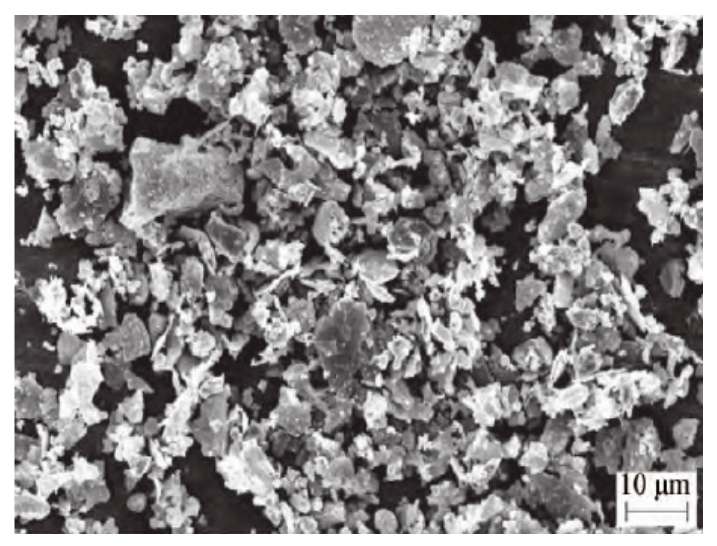

Figure 12. SEM image of a high-performance filler.

A calcium sulfate whisker, as a functional filler, has a certain effect on tribological properties. Four calcium sulfate whisker with different contents $(0,5,10$, and $15 \mathrm{wt} \%$ by weight) were used for experimental research. It is recorded as $C_{0}, C_{1}, C_{2}$, and $C_{3}$. Figure 13 shows the wear of the four materials under SEM, where (a) represents $C_{0}$, (b) represents $C_{1}$, (c) represents $C_{2}$, and (d) represents $\mathrm{C}_{3}$. It can be seen that the addition of calcium sulfate whisker improves the wear of the material surface and increases the wear resistance of the material surface [28].

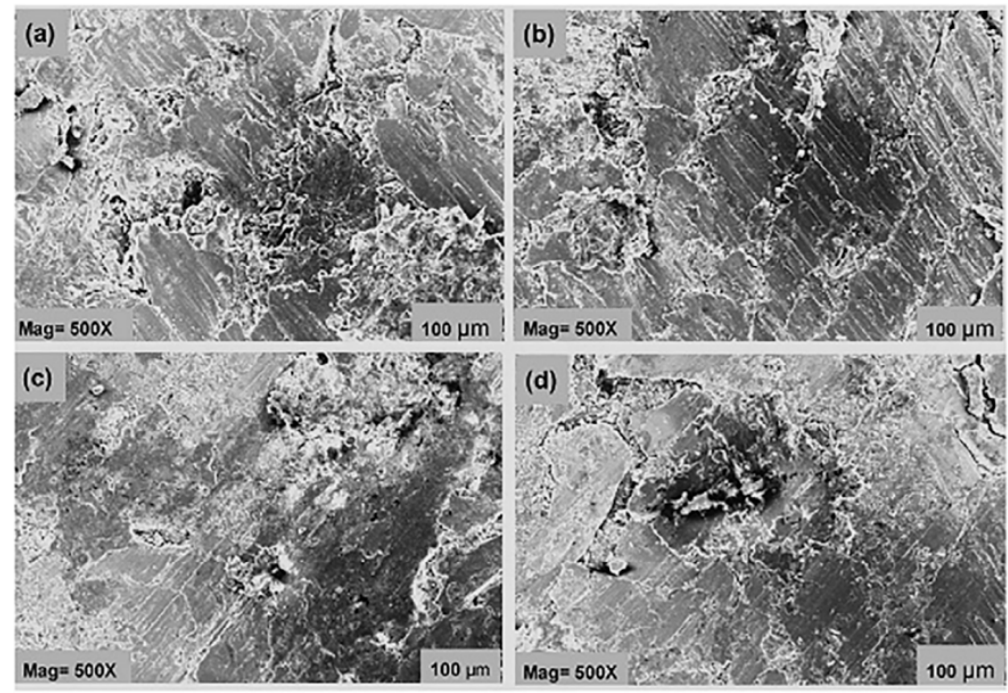

Figure 13. The worn surface under the scanning electron microscope. (a) $C_{0} ;(\mathbf{b}) C_{1} ;$ (c) $C_{2} ;(d) C_{3}$.

Therefore, the study of reducing or increasing friction of inorganic particles as a filler in composites has great significance to the development of composites.

Friction materials have the function of transmission, braking, deceleration, and parking in mechanical transmission. The study on the properties of various friction materials in composites can further reveal the friction and wear properties of composites. Reinforced fibers are the supporting framework of the friction materials. It can improve the mechanical strength of the friction material and withstand the strong impact and shear of braking. Reinforced fibers give the friction material some toughness. Asbestos fibers were often used as reinforced fibers in the past. However, because of the carcinogenicity of asbestos, the study of alternative fibers began. Currently, the widely used substitute fibers include organic and inorganic. Organic fibers include polyethylene fibers, polyester fibers, cotton, and hemp. Inorganic fibers include glass fibers, carbon fibers, metal fibers, boron fibers, whiskers, etc. 
A new type of asbestos-free friction material is developed, which is made of resin as matrix and glass fiber as reinforcing material. By the heat-treat, plasma treatment and coupling agent treatment of glass fiber, the wear mass loss of material is reduced. Additionally, the friction and wear properties of the material are improved.

Carbon fiber reinforced resin-based friction material is a friction material with good properties. The resin-based friction material has the advantages of excellent friction and wear performance, simple preparation process, strong performance and designability, and low cost. At high temperatures, the resin-based friction materials decompose and decay, the friction coefficient decreases and the wear rate increases [49]. A variety of reinforced fibers can be used for the filling modification of resin-based friction materials, such as glass fiber, metal fiber, carbon fiber, ceramic fiber, etc. Among them, carbon fiber has a stable friction factor and good abrasion resistance. In addition, it is a composite that has a reliable performance, long service life, and low-contamination [50]. Carbon fiber has a graphite-like structure, which gives the reinforced friction materials a better self-lubrication and antifriction effect [51]. The thermal degradation resistance of the friction material reinforced by carbon fiber is improved obviously. It has a lower wear rate at low speed, low temperature, and a wide load range. Additionally, carbon fiber has high thermal stability. It exhibits better wear resistance under high braking pressure. Studies have shown that carbon fiber reinforced paper-based friction material has lower porosity. With a carbon fiber content approximately $55 \mathrm{wt} \%$, the paper-based friction material has a stable friction factor. In addition, with a carbon fiber content approximately $40 \mathrm{wt} \%$, the paper-based friction material has good abrasion resistance $[52,53]$. The increase of carbon fiber content can improve the hardness, compression strength, and shear strength of materials. The addition of nanoparticles to friction materials improved the microinterfacial structural components. It improved physical properties and comprehensive properties of materials, and it increased wear resistance and heat resistance.

\subsection{New Structure and New Materials}

On the basis of not changing the base materials of brake discs, from the perspective of the internal structure improvement and external feature design, the research and development with a new structure are realized. It has relatively high innovation. However, the modification of the brake discs is not large, the production structures are complex and diverse. So, it is difficult to achieve mass production.

There is an international study about using palm kernel as reinforced composites. These brake pads can use natural fibers such as palm kernel, the Nile rose, and wheat instead of alumina and graphite powder as reinforced composites. In this work, palm kernel fiber particles are mixed with alumina powder and graphite powder into type 1 composites in a certain ratio. Palm kernel fiber is mixed with the Nile rose, wheat, aluminum, and graphite powder into type 2 composites. Table 4 shows the specific wear rate of palm kernel particles at different speeds and different volume fractions of type 1 composites. Table 5 shows the specific wear rate of palm kernel particles at different speeds and different volume fractions of type 2 composites. Figures 14-16 present the analysis results of the study. Studies have found that the hardness of type 1 composites is greater than type 2 composites [54].

Table 4. Specific wear rates of palm-kernel particles of type 1 composites at different velocities and volume fractions.

\begin{tabular}{cccc}
\hline \multirow{2}{*}{ Sample Number } & \multicolumn{3}{c}{ Specific Grinding Rate $/\left(\mathbf{m m}^{\mathbf{3}} \cdot(\mathbf{N} \cdot \mathbf{m})^{-\mathbf{1}}\right)$} \\
\cline { 2 - 4 } & At $\mathbf{3 5 0} \mathbf{~ r p m}$ & At $\mathbf{4 5 0} \mathbf{~ r p m}$ & At $\mathbf{5 5 0} \mathbf{~ r p m}$ \\
\hline$S_{1}$ & 0.000197 & 0.000230 & 0.000188 \\
$S_{2}$ & 0.001970 & 0.001690 & 0.001130 \\
$S_{3}$ & 0.000390 & 0.000460 & 0.000629 \\
$S_{4}$ & 0.000197 & 0.000230 & 0.000314 \\
$S_{5}$ & 0.000098 & 0.000380 & 0.000250 \\
\hline
\end{tabular}


Table 5. Specific wear rates of palm-kernel particles of type 2 composites at different velocities and volume fractions.

\begin{tabular}{cccc}
\hline \multirow{2}{*}{ Sample Number } & \multicolumn{3}{c}{ Specific Grinding Rate $/\left(\mathbf{m m}^{\mathbf{3}} \cdot(\mathbf{N} \cdot \mathbf{m})^{-\mathbf{1}}\right)$} \\
\cline { 2 - 4 } & At $\mathbf{5 5 0} \mathbf{~ r p m}$ & At $\mathbf{4 5 0} \mathbf{~ r p m}$ & At $\mathbf{5 5 0} \mathbf{~ r p m}$ \\
\hline $\mathrm{S}_{1}$ & 0.000520 & 0.001640 & 0.000840 \\
$\mathrm{~S}_{2}$ & 0.001180 & 0.001130 & 0.000840 \\
$\mathrm{~S}_{3}$ & 0.000260 & 0.000710 & 0.000925 \\
$\mathrm{~S}_{4}$ & 0.001320 & 0.002050 & 0.002430 \\
$\mathrm{~S}_{5}$ & 0.002640 & 0.002050 & 0.001680 \\
\hline
\end{tabular}

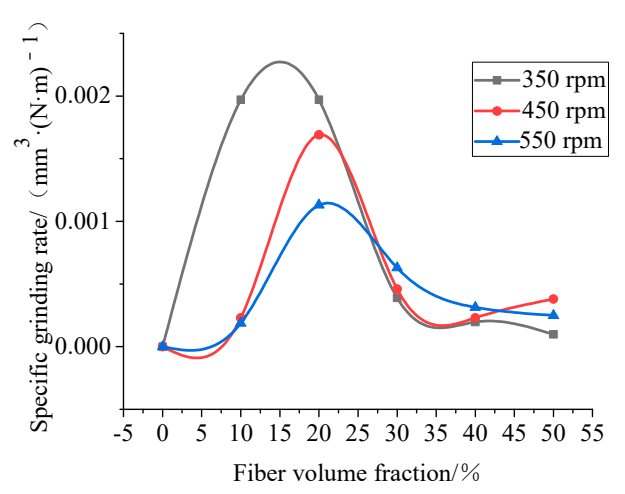

Figure 14. Influence of the palm kernel volume fraction on the wear rate of the type 1 composite material.

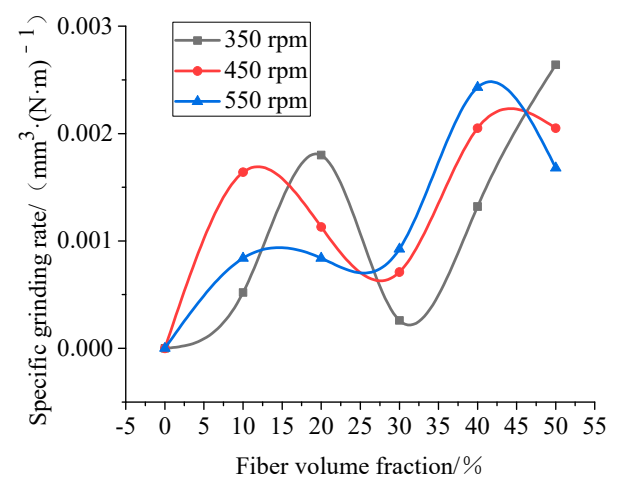

Figure 15. Effect of the volume fraction on the wear rate of type 2 composites.

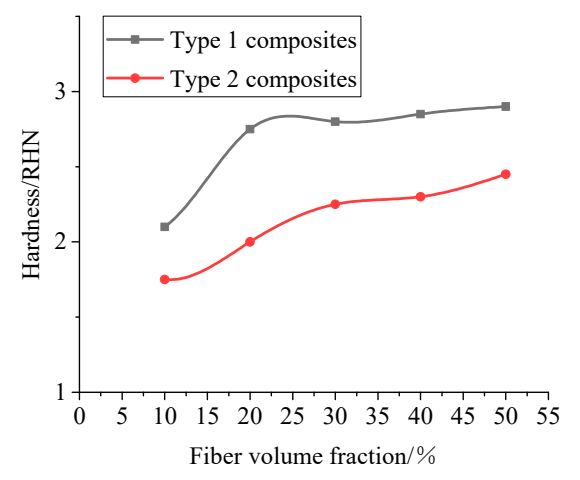

Figure 16. Influence of fiber volume fraction on the hardness of various composites.

\section{Conclusions}

Currently in China, cast iron is the main base material of brake discs, while some high-end automobiles use aluminum alloy, ceramics, and composite oxide films. Taking brake discs' performance into consideration, undoubtedly high-end automobiles' base materials are better. Compared with other 
metal fibers such as steel, ceramics are a relatively new friction material. They are mostly composed of metal oxides, carbides, and silicon carbide. Ceramics have a higher thermal resistance. The melting point is between 1850 and $3000^{\circ} \mathrm{C}$. Additionally it is light in weight and strong in strength [55].

The manufacturing cost of carbon fiber brake discs is only slightly higher than that of steel fiber discs. Considering the performance, life, and noise, its comprehensive performance is better than steel fiber discs. With the development and research of carbon fiber, the price of carbon fiber will inevitably decrease. In addition, its production capacity will certainly increase. Therefore, carbon fiber brake discs will be one of the main topics of future brake disc research.

Author Contributions: Conceptualization, X.Y. and W.L.; methodology, X.Y. and W.L.; software, W.L.; validation, W.L. and X.Y.; formal analysis, W.L.; investigation, W.L.; resources, X.X.; data curation, W.L.; writing-original draft preparation, W.L.; writing-review and editing, X.Y.; visualization, W.L.; supervision, J.X. and Q.H.; project administration, X.Y.; funding acquisition, X.Y. and S.W. All authors have read and agreed to the published version of the manuscript.

Funding: This research was funded by the National Natural Science Foundation of China, (grant No. 51575234,515872122), the Postdoctoral Science Foundation of China (grant No. 2017M620286), the Key Research and Development Program of Shandong Province, China (grant No. 2018CXGC0809), the Agricultural Machinery Equipment Research and Development Innovation Plan of Shandong Province (grant No. 2018YF012), experts from Taishan Scholars and Youth Innovation in Science and Technology Support Plan of Shandong Province University.

Conflicts of Interest: The authors declare no conflict of interest.

\section{References}

1. Long, W.; Choy, Y.S.; Cheung, C.S. A study of brake contact pairs under different friction conditions with respect to characteristics of brake pad surfaces. Tribol. Int. 2019, 138, 99-110.

2. Lu, W. Cast Iron and Smelting; Mechanical Industry Publisher: Beijing, China, 1981.

3. Riahi, A.R.; Alpas, A.T. Wear map for grey cast iron. Wear 2003, 255, 401-409. [CrossRef]

4. Sugishita, J.; Fujiyoshi, S. The effect of cast iron graphites on friction and wear performance I: Graphite film formation on grey cast iron surfaces. Wear 1981, 66, 209-221. [CrossRef]

5. Eyre, T.S.; Iles, R.F.; Gasson, D.W. Wear characteristics of flake and nodular graphite cast iron. Wear 1969, 13, 229-245. [CrossRef]

6. Montgomery, R.S. Run-in and glaze formation on gray cast iron surfaces. Wear 1969, 14, 99-105. [CrossRef]

7. Terheci, M.; Manory, R.R.; Hensler, J.H. The Friction and Wear of Automotive Grey Cast Iron under Dry Sliding Conditions Part 2. Friction and Wear-Particle Generation Mechanisms and Their Progress with Time. Wear 1995, 185, 119-124. [CrossRef]

8. Majcherczak, D.; Dufrenoy, P. Third body influence on Thermal friction contact problems: Application to braking. J. Tribol. 2005, 127, 89-95. [CrossRef]

9. Aleksandrov, M.P.; Nosko, A.L. Design for heat in braking system with small angle of mutual overlapping. Sumitomo Met. 1991, 45, 2-32.

10. Benseddiq, N.; Weichet, D.; Seidermann, J.; Minet, M. Optimization of design of railway disc brake pads. J. Rail. Rapid. Trandsit. 1996, 210, 51-61. [CrossRef]

11. Holmgren, D.; Dioszegi, A.; Svensson, I.L. Effects of Carbon Content and Solidification Rate on the Thermal Conductivity of Grey Cast Iron. Tsinghua Sci. Technol. 2008, 2, 170-176. [CrossRef]

12. Fritz, G.; Sinou, J.J.; Duffal, J.M.; Jezequel, L. Effects of damping on brake squeal coalescence patterns-application on a finite element model. Mech. Res. Commun. 2006, 34, 181-190. [CrossRef]

13. Hecht, R.L.; Dinwiddie, R.B.; Wang, H. The effect of graphite brake morphology on the thermal diffusivity of gray cast irons used for automotive brake discs. J. Mater. Sci. 1999, 34, 4775-4781. [CrossRef]

14. Lazzari, A.; Tonazzi, D.; Massi, F. Squeal propensity characterization of brake lining materials through friction noise measurements. Mech. Syst. Signal Process. 2019, 128, 216-288. [CrossRef]

15. Blaschke, P.; Tan, M.; Wang, A. On the Analysis of Brake Squeal Propensity Using Finite Element Method; SAE Technical Paper: Warrendale, PA, USA, 2000. [CrossRef]

16. Liu, P.; Zheng, H.; Cai, C. Analysis of disc brake squeal using the complex eigenvalue method. Appl. Acoust. 2007, 68, 603-615. [CrossRef] 
17. Massi, F.; Baillet, L.; Giannini, O.; Sestieri, A. Brake squeal: Linear and nonlinear numerical approaches. Mech. Syst. Signal Process. 2006, 21, 2374-2393. [CrossRef]

18. Abdelounis, H.B.; Bot, A.L.; Liaudet, J.P.; Zahouani, H. An Experimental Study on Roughness Noise of Dry Rough Flat Surfaces. Wear 2010, 268, 335-345. [CrossRef]

19. Hammersrom, L.; Jacobson, S. Surface Modification of Brake Discs to Reduce Squeal Problems. Wear 2006, 261, 53-57. [CrossRef]

20. Chen, F.; Tong, H.; Chen, S.E. On Automotive Disc Brake Squeal Part IV: Reduction and Prevention; SAE Technical Paper: Warrendale, PA, USA, 2003. [CrossRef]

21. Zhang, H.; Mullen, R.L.; Muhanna, R.L. Interval Monte Carlo methods for structural reliability. Struct. Saf. 2010, 32, 183-190. [CrossRef]

22. Liaquat, H.; Shi, X.L.; Yang, K.; Huang, Y.; Liu, X.; Wang, Z. Tribological behavior of TiAl metal matrix composite brake disk with tic-reinforcement under dry sliding conditions. J. Mater. Eng. Perform. 2017, 26, 3457-3464. [CrossRef]

23. Bosnjak, B.; Radulovic, B.; Tonev, K.P. Influence of micro-alloying and heat treatment on the kinetics of bainitic reaction in austempered ductile iron. J. Mater. Eng. Perform. 2001, 10, 203-211. [CrossRef]

24. Refaey, A.; Fatahalla, N. Effect of microstructure on properties of ADI and low alloyed ductile iron. J. Mater. Sci. 2003, 38, 351-362. [CrossRef]

25. Luan, J.F. Microstructure and wear resistance of ductile cast iron laser clad with Ni-Ti-Co-C. J. Mater. Sci. Technol. 1999, 15, 222-224.

26. Tomlinson, W.J.; Cash, M. Dry sliding wear of grey iron laser surface cladded with $14 \%-40 \%$ chromium. Wear 1991, 142, 383-386. [CrossRef]

27. Barros, L.Y.; Poletto, J.C.; Neis, P.D.; Ferreira, N.F.; Pereira, C.H. Influence of copper on automotive brake performance. Wear 2019, 426, 741-749. [CrossRef]

28. Jeganmohan, S.R.; Christy, T.V.; Solomon, D.G.; Sugozu, B. Influence of calcium sulfate whiskers on the tribological characteristics of automotive brake friction materials. Eng. Sci. Technol. 2019. [CrossRef]

29. Cueva, G.; Sinatora, A.; Guesser, W.L.; Tschiptschin, A.P. Wear resistance of cast irons used in brake disc rotors. Wear 2003, 255, 1256-1260. [CrossRef]

30. Sun, J.Q.; Yan, Z.F.; Cui, H.Z.; Li, J.; Wang, J.S.; Chen, Y.B. Surface catalysis gaseous nitriding of alloy cast iron at lower temperature. Catal. Today 2010, 158, 205-208. [CrossRef]

31. Li, C.X.; Sun, Y.; Bell, T. Factors influencing fretting fatigue properties of plasma-nitrided low alloy steel. Mater. Sci. Eng. A 2000, 292, 18-25. [CrossRef]

32. Cao, Y.J. Effect of the microstructure and residual stress on tribological behavior of induction hardened GCr15 steel. Tribol. Int. 2017, 115, 108-115. [CrossRef]

33. Corengia, P.; Walther, F.; Ybarra, G.; Sommadossi, S.; Corbari, R.; Broitman, E. Friction and rolling-sliding wear of DC-pulsed plasma nitrided AISI 410 martensitic stainless steel. Wear 2006, 260, 479-485. [CrossRef]

34. Yen, B.K.; Ishihara, T. On temperature dependent tribological regimes and oxidation of carbon-carbon composites up to $18000^{\circ} \mathrm{C}$. Wear 1996, 196, 254-262. [CrossRef]

35. Yen, B.K.; Ishihara, T. An investigation of friction and wear mechanisms of carbon-carbon composites in nitrogen and air atelevated temperatures. Carbon 1996, 34, 489-498. [CrossRef]

36. Chen, J.D.; Chern, L.J.H.; Ju, C.P. Effect of load on tribological behavior of carbon-carbon composites. J. Mater. Sci. 1996, 193, 38-47.

37. Murdie, N.; Ju, C.P.; Don, J.; Fortunato, F.A. Microstructure of worn pitch-resin-CVI C-C composites. Carbon 1991, 29, 335-342. [CrossRef]

38. Awasthi, S.; Wood, J.L. C/C composites materials for aircraft brakes. Adv. Ceram. Mater. 2008, 3, 553-559. [CrossRef]

39. Houdayer, M.; Spitz, J.; Tran, V.D. Process for the Densification of a Porous Structure. US Patent US4472454, 18 September 1984.

40. Scaringgella, D.T.; Connors, D.E.; Thurston, G.S. Method for Densifying and Refurbishing Brakes. US Patent US5547717, 20 August 1996.

41. Kuo, H.H.; Lin, J.H.C.; Ju, C.P. Tribological behavior of fast-carbonized PAN/phenolic-based carbon/carbon composite and method for improving same. Wear 2005, 258, 1555-1561. [CrossRef]

42. Cai, P.; Wang, Y.; Wang, T.; Wang, Q. Effect of resins on thermal, mechanical and tribological properties of friction materials. Tribol. Int. 2015, 87, 1-10. [CrossRef] 
43. Neis, P.D.; Ferreira, N.F.; Silva, F.P.D. Comparison between methods for measuring wear in brake friction materials. Wear 2014, 319, 191-199. [CrossRef]

44. Chan, D.; Stachowiak, G. Review of automotive brake friction materials. Proc. Inst. Mech. Eng. Part D J. Automob. Eng. 2004, 218, 953-966. [CrossRef]

45. Cho, M.H.; Ju, J.; Kim, S.J.; Jang, H. Tribological properties of solid lubricants (graphite, $\mathrm{Sb}_{2} \mathrm{~S}_{3}, \mathrm{MoS}_{2}$ ) for automotive brake friction materials. Wear 2006, 260, 855-860. [CrossRef]

46. Singh, T.; Patnaik, A.; Gangil, B.; Chauhan, R. Optimization of tribo-performance of brake friction materials: Effect of nano filler. Wear 2015, 324, 10-16. [CrossRef]

47. Cho, K.H.; Jang, H.; Hong, Y.S.; Kim, S.J.; Basch, R.H.; Fash, J.W. The size effect of zircon particles on the friction characteristics of brake lining materials. Wear 2008, 264, 291-297. [CrossRef]

48. Bijwe, J.; Aranganathan, N.; Sharma, S.; Dureja, N.; Kumar, R. Nano-abrasives in friction materials-influence on tribological properties. Wear 2012, 296, 693-701. [CrossRef]

49. Hong, U.S.; Jung, S.L.; Cho, K.H.; Cho, M.H.; Kim, S.J.; Jang, H. Wear mechanism of multiphase friction materials with different phenolic resin matrices. Wear 2009, 266, 739-744. [CrossRef]

50. Betancourt, S.; Cruz, J.; Toro, A. Friction and wear in sliding contact of cast iron against phenolic resin composites reinforced with carbonaceous fibres from plantain fibre bundles. Lubr. Sci. 2013, 25, 163-172. [CrossRef]

51. Fei, J.; Li, H.L.; Fu, Y.W.; Qi, L.H.; Zhang, Y.L. Effect of phenolic resin content on performance of carbon fiber reinforced paper-based friction material. Wear 2010, 269, 534-540. [CrossRef]

52. Fu, H.; Liao, B.; Qi, F.J.; Sun, B.C.; Liu, A.P.; Ren, D.L. The application of PEEK in stainless steel fiber and carbon fiber reinforced composites. Compos. Part B Eng. 2008, 39, 585-591. [CrossRef]

53. Fei, J.; Luo, W.; Huang, J.F.; Ouyang, H.; Xu, Z.; Yao, C. Effect of carbon fiber content on the friction and wear performance of paper-based friction materials. Tribol. Int. 2015, 87, 91-97. [CrossRef]

54. Pujari, S.; Srikiran, S. Experimental investigations on wear properties of Palm kernel reinforced composites for brake pad applications. Def. Technol. 2019, 15, 295-299. [CrossRef]

55. Venkatesh, S.; Murugapoopathiraja, K. Scoping review of brake friction material for automotive. Mater. Today Proc. 2019, 16, 927-933. [CrossRef]

(C) 2020 by the authors. Licensee MDPI, Basel, Switzerland. This article is an open access article distributed under the terms and conditions of the Creative Commons Attribution (CC BY) license (http://creativecommons.org/licenses/by/4.0/). 